\title{
Determinants of Technical Inefficiency of Handloom Weaving Industry in Kushtia District of Bangladesh: A Tobit Model Approach
}

\author{
Md. Khairul Islam, Md. Elias Hossain \\ Department of Economics, University of Rajshahi, Rajshahi, Bangladesh
}

Email address:

khairu106eco@gmail.com (M. K. Islam), eliaseco@ru.ac.bd (M. E. Hossain)

To cite this article:

Md. Khairul Islam, Md. Elias Hossain. Determinants of Technical Inefficiency of Handloom Weaving Industry in Kushtia District of Bangladesh: A Tobit Model Approach. Journal of Investment and Management. Vol. 4, No. 4, 2015, pp. 95-99.

doi: 10.11648/j.jim.20150404.11

\begin{abstract}
This paper is an attempt to analyze the determinants of technical inefficiency of handloom weaving units operating in Kumarkhali Upazila of Kushtia District in Bangladesh. The study is mainly based on primary data that are collected through structured questionnaire from handloom unit owners in the study area. A total of 57 handloom units are randomly selected for the study. Cobb-Douglas production function model is employed to obtain the technical efficiency of handloom units and technical inefficiency index is calculated from the obtained efficiencies. Tobit Model is used to identify the factors of inefficiency in the handloom weaving units. From the analysis, average inefficiency of handloom units in the study area is found to be 0.245 . The major findings of the study show that education, experience, size of unit, and age of owners are significant factors influencing technical inefficiency of handloom weaving units.
\end{abstract}

Keywords: Handloom Industry, Technical Inefficiency, Determinants, Tobit Model, Bangladesh

\section{Introduction}

The handloom industry is one of the traditional cottage industries in Bangladesh. Next to agriculture, it is the second largest source of rural income and employment in the country (Ahmed, 1999). Handloom sector consists of more than 0.183 million handloom units (factories) with 0.505 million looms. About one million weavers have been working in the industry of which around $50 \%$ are female ( $\mathrm{GoB}, 2003)$. Handloom industry generates remarkable benefits for Bangladesh economy in terms of micro- and macroeconomic impacts. It plays vital role to reduce poverty, increase employment, and enhance household income and consumption in the country. Thus, in Bangladesh, handloom sector has positive contribution to employment generation and economic growth. Out of total 505556 handlooms only 313245 are in operation now and the rest 192311 are nonoperational (GoB, 2003). Now the industry is on the declining trend due to a number of factors including lack of education, skill, and experience of owners and weavers, lack of loan facilities, absence of organization of the weavers, smuggling of cloth from other countries, lack of working capital etc. Raihan (2010) reports that presently about 0.2 million looms are closed in Bangladesh due to the lack of working capital only. However, these are not the only reasons behind non-operation of the looms. In addition, the handloom unit owners cannot achieve maximum possible output due to failure of choosing the optimal combination of inputs as they do not have higher education, skill, experience, training and well management capacity. For these reasons, the owners fail to minimize input use to produce a certain level of output. This failure makes their units less profitable and hence, they are forced to close down their units over time. If they are able to use efficient input combination, the handloom production would become more profitable and generate more employment and income. As a result poverty would be reduced. Therefore, it is important to identify whether inefficiency exists in the industry and also to identify the factors that contribute to increase or decrease inefficiency in the handloom industry. Thus, the main objective of the study is to identify the factors contributing to technical inefficiency among the handloom weaving units and quantify the effects of such factors on technical inefficiency. The specific objectives of this study are as follows:

(1) To estimate the level of technical inefficiency exists in the handloom weaving units in the study area. 
(2) To identify the factors of technical inefficiency of handloom units in the study area.

(3) To analyze the effects of such factors on technical inefficiency.

\section{Efficiency Concepts}

Technical efficiency is a major component of productivity which shows the performance of an industry. Technical efficiency indicates whether an industry uses the best available technology. It reflects the ability of a firm to obtain maximum output from a given set of inputs (Coelli et al., 1998). A technically efficient industry operates on the production frontier and on the other hand, technically inefficient industry operates below the frontier, could operate on the frontier either by increasing output with the same input bundle or using less input to produce the same output. The closer an industry gets to the frontier, the more it will be technically efficient. Figure 1 shows a graphical illustration of a production efficiency frontier, put forward by Farrell (1957). An industry for example, at point $X$ refers to be inefficient, while points $\mathrm{Y}$ and $\mathrm{Z}$ are both efficient because they are on the frontier. The industry at point $X$ should therefore, move upward to point $\mathrm{Y}$ or backward to point $\mathrm{Z}$ in order to be efficient. If its movement is toward $\mathrm{Y}$, more output is obtained with the same amount of inputs or if it is toward Z, fewer amounts of inputs yield the same output. Both cases depict more technical efficiency than the initial position $\mathrm{X}$.

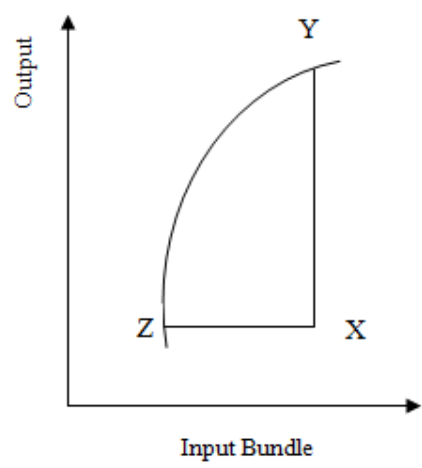

Figure 1. Production Frontier.

The position of individual firms relative to the frontier would be influenced by factors such as environmental, structural and industry characteristics include the capitallabor ratio (degree of mechanization), size of unit, operator's characteristics, geographical location, management practices and strategies as well as business organization and arrangement of industry.

\section{Literature Review}

There are several studies which dealt with the issue of comparative economic efficiency of handloom weaving units, power loom units, and the mills. Chowdhury (1981) did a costbenefit analysis of weaving by handlooms, power looms, and mills in Bangladesh. He calculated financial and economic internal rates of return (IRR) of these three alternative techniques of production. He found that handloom is economically a more efficient technique. Rahman (1980) examined the relative economic efficiency of weaving on handloom, the power loom and the mill. He also found that handlooms are more efficient than that of power looms and mills. Wasow et al. (1984) reexamined the relative efficiency of handloom and power loom. He found that the handlooms perform as well as or better than power looms. McKay (1984) estimated comparative efficiency of handloom and power loom techniques on the basis of the computation of internal rates of return (IRR) and domestic resource cost (DRC). He found that the comparative efficiency of handloom is higher than that of power loom. Jaforullah (1999) estimated the technical efficiency of handloom weaving industry in Bangladesh. He showed that technical efficiency of handloom industry of Bangladesh is only $41 \%$ and its technical efficiency might be improved by increasing its male and female labor ratio and decreasing its hired/family labor ratio and laborcapital ratio.

In addition to analyzing economic efficiency, some earlier studies analyzed other issues related to handloom weaving industry. Rahman (2013) analyzed the prospects of handloom weaving industry in Pabna district of Bangladesh. The study identified all the internal and external factors that help to understand the present condition of the handloom industry operating in Pabna district. The study found that shortage of working capital, high cost of raw materials, lack of organizing capability, inadequate technology and efficiency, lack of policy support, huge knowledge gap, lack of power supply and shortage of credit facilities are the main features of the handloom units operating in Pabna district of Bangladesh.

Islam and Hossain (2014) studied the contribution of factor costs to gross return of handloom weaving industry in Kumarkhali Upazila of Kushtia District in Bangladesh. The study found that labor, yarn and capital costs have significant and positive contribution to gross return. Thus, the study concluded that handloom unit owners can have more gross return by increasing the use of labor, yarn and capital costs.

Islam et al. (2013) analyzed the cost and benefit of handloom weaving units operating in Kumarkhali Upazila of Kushtia District. The cost-benefit analysis found that handloom weaving activity is profitable and profit per-loom for small scale and large scale units are higher than that of the medium scale units.

Tanusree (2015) studied the present situation of the traditional handloom weavers of Varanasi in Uttar Pradesh of India. The study found that after the industrialization, the handloom units operating in India has declined. The problems that are faced by handloom industry are invention of powerloom, capitalist control, drop off in wages, and increase in yarn price.

From the review of above literature it is found that there are some limitations in the previous literature, which needs to be taken into account to conduct further study on handloom weaving industry. It is observed that the previous researchers 
analyzed the problems of handloom industry, cost-benefit situation of the industry, factors of gross return and other issues related to handloom industry in Bangladesh and elsewhere. Moreover, some earlier studies analyzed the comparative profitability of weaving units- handlooms, power looms and mills in Bangladesh. However, to the best of our knowledge none of the earlier studies analyzed the technical inefficiency of handloom units and also the factors which are responsible for the inefficiency of handloom weaving industry were not identified in the case of Bangladesh. Therefore, it is necessary to investigate the level of inefficiency in the handloom units and the factors that influence inefficiency as it is important to increase the productivity of the industry.

\section{Methodology}

\subsection{Study Area and Data Collection}

The present study depends on primary data collected from the owners of handloom units of three villages of Kumarkhali Upazila of Kushtia District in Bangladesh. Handloom is a traditional industry in Bangladesh and Kumarkhali Upazila has special reputation in this regard as there are many handloom-units concentrated in different areas of Kumarkhali Upazila. Therefore, this Upazila has been chosen purposively for this study. The Upazila has 11 unions and the headquarter. First of all three unions from all the unions are selected randomly (the head quarter was also considered as a union). In the next stage one village from each union is selected randomly. For selecting the respondents, at first the list of total handloom owners in the study area has been collected from Bangladesh Handloom Board (BHB), Kumarkhali branch. Then the respondents are selected from that list randomly. They are interviewed during the period of data collection and the information on inputs (labor, capital, yarn etc., production and industry characteristics (such as education, experience, size of unit, age of owners, wages of labor, loan facility, and number of master weaver etc.) were collected directly from the handloom unit owners by the use of structured questionnaire.

\subsection{The Empirical Model}

Cobb-Douglas production function model within the framework of Stochastic Frontier approach has been employed to estimate the technical efficiency of handloom units in the study area at the first stage. Then the method used by Featherstone et al. (2004) was followed to compute the technical inefficiency indices by subtracting the technical efficiency estimates from 1 . The ratio of capital to labor (proxy for the degree of mechanization) and industry characteristics such as education, experience, size of unit, age of owners, wages of labor, loan facility and number of

$$
T F I_{i}=\beta_{0}+\beta_{1} X_{1}+\beta_{2} X_{2}+\beta_{3} X_{3}+\beta_{4} X_{4}+\beta_{5} X_{5}+\beta_{6} X_{6}+\beta_{7} X_{7}+\beta_{8} X_{8}+\mu_{i}
$$

Where, the dependent variable $\mathrm{TFI}_{\mathrm{i}}$ is the inefficiency of handloom weaving industry in the study area. $\mathrm{X}_{1}$ is the ratio of capital to labor (proxy for the degree of mechanization), master weaver etc. are assumed to have significant influence on inefficiency of handloom weaving units. Considering this assumption, capital-labor ratio, education, experience, size of unit, age of owners, wages of labor, loan facility, and number of master weaver were used in this study as variables in the model. The inefficiency function for the sample owners of the handloom weaving industry is:

$$
T I F=f\left(X_{1}, X_{2}, X_{3}, X_{4}, X_{5}, X_{6}, X_{7}, X_{8}\right)
$$

Where, TIF, $\mathrm{X}_{1}, \mathrm{X}_{2}, \mathrm{X}_{3}, \mathrm{X}_{4}, \mathrm{X}_{5}, \mathrm{X}_{6}, \mathrm{X}_{7}$, and $\mathrm{X}_{8}$ stands for technical inefficiency, capital-labor ratio, education, experience, size of unit, age of owners, wages of labor, loan facility, and number of master weaver, respectively. An attempt has been made here to determine the effect of these factors on the inefficiency of handloom units. In this study, a maximum likelihood regression method is used to estimate the function showing the relationship between inefficiency and key factors of inefficiency.

\subsection{The Tobit Model}

A Tobit model was used to estimate the effects of various quantitative and qualitative factors on the inefficiency of handloom weaving units in Kumarkhali Upazila of Kushtia District. The Tobit model is a censored normal regression model and its estimations are related to the estimation of a censored and truncated normal distribution (Amemiya, 1973). The technical inefficiency model in a Tobit regression framework is stated as follows:

$$
\begin{aligned}
\text { TIF }_{i} & =\sum_{i=1}^{n} \beta_{i} X_{i}+u_{i} \text {, if } L_{i}<\sum_{\mathrm{i}=1}^{\mathrm{n}} \beta_{i} X_{i}+u_{i}<\mathrm{U}_{\mathrm{i}} \\
& =0 \text { otherwise }
\end{aligned}
$$

Where, $\mathrm{TIF}_{\mathrm{i}}$ is the technical inefficiency measure for each unit, $\mathrm{X}_{\mathrm{i}}$ is $\mathrm{k} \times 1$ vector of explanatory variables for the $\mathrm{i}^{\text {th }}$ unit, $\beta_{\mathrm{i}}$ is $\mathrm{k} \times 1$ vector of unknown parameters to be estimated, $u_{i}$ are residuals that are independently and normally distributed, with mean zero and a common variance $\sigma^{2} . L_{i}$ and $U_{i}$ are the distribution's lower and upper censoring points, respectively. The explanatory variables are the capital-labor ratio (proxy for the degree of mechanization) and industry characteristics such as education, experience, size of unit, age of owners, wages of labor, loan facility, and number of master weaver.

\subsection{Specification of the Empirical Model}

The empirical relationship between the dependent variable and the set of explanatory variables on the inefficiency of handloom industry is specified using the following linear relationship.

$\mathrm{X}_{2}$ is the educational status of owners (year), $\mathrm{X}_{3}$ is the experience of owners (year), $\mathrm{X}_{4}$ is the size of unit (no. of loom in the unit), $\mathrm{X}_{5}$ is the age of owners (year), $\mathrm{X}_{6}$ is the 
wages of labor (in Tk.), $\mathrm{X}_{7}$ is the loan facilities (dummy $\mathrm{D}_{1}$ $=1$, if owner obtain loan and $D_{1}=0$ otherwise), and $X_{8}$ is the number of master weaver working in the unit. We regard the sample as truncated-censured since the study focuses mainly on the units operating in the time of study. $\beta_{0}, \beta_{1}, \beta_{2}, \beta_{3}, \beta_{4}, \beta_{5}$, $\beta_{6}, \beta_{7}$ and $\beta_{8}$ are regression coefficients and $u_{i}$ is the random error term which is normally distributed. The coefficients of the regression model were estimated by applying the maximum likelihood estimation (MLE) technique. In this paper, all observations have positive (non zero) technical inefficiency estimates.

\section{Results and Discussion}

The descriptive statistics of the variables used in the Tobit model and the maximum likelihood estimates of the model for inefficiency of handloom weaving industry in Kumarkhali Upazila of Kushtia District in Bangladesh are presented in Table 1 and Table 2.

\subsection{Descriptive Statistics of the Variables Used in the Tobit Model}

The summary statistics of all the variables used are presented in Table 1. The average inefficiency of handloom weaving units in the study area is $24.5 \%$ by which the units should increase output in order to produce on the frontier. The average size of a unit is 5.72 looms per unit. This indicates that handloom owners are small scale producers although the minimum and maximum unit sizes are 1 and 16 looms per unit.

Table 1. Descriptive Statistics on the Variables Used in the Tobit Model.

\begin{tabular}{lllll}
\hline Variables & Mean & Std. Dev. & Minimum & Maximum \\
\hline Inefficiency & 0.245 & 0.1695 & 0.056 & 0.74 \\
Education (years) & 4.11 & 3.9762 & 0 & 10 \\
Experience (years) & 24.53 & 8.5963 & 10 & 45 \\
Age of owners (years) & 39.54 & 8.6892 & 25 & 60 \\
Capital-labor ratio & 0.10 & 0.0522 & 0.019 & 0.21 \\
Size of unit (no. of loom) & 5.72 & 4.1177 & 1 & 16 \\
Wages of labor (per-day) & 209.05 & 21.089 & 150 & 300 \\
\hline
\end{tabular}

Source: Authors own calculation

It is found from the analysis that average of capital-labor ratio (proxy for degree of mechanization)in the units is 0.10 and the average education level of handloom owners is 4.11 years of schooling. The low degree of mechanization could mean that most of the owners under investigation have lower level of education, upon which the degree of mechanization is usually based. Average age of the owners in the study area is 39.54 years whereas the average firming experience of the owners is 24.53 years. The average per-day wages of labor in the study area is Tk. 209.05.

\subsection{Regression Results}

In order to identify the factors determining technical inefficiency of the handloom weaving units the specified Tobit regression (Equation 3) has been estimated. The maximum likelihood estimates of the marginal effects of the explanatory variables on technical inefficiency of handloom weaving industry in Kumarkhali Upazila of Kushtia District are presented in Table 2. The final results show that capitallabor ratio, education, experience, size of unit, age of owners (with values of $-8.5 \%,-3.1 \%,-9.1 \%,-7.6 \%$, and $-7.1 \%$, respectively) are significant factors influencing technical inefficiency, with only 'age of owners' having a positive influence, while others have the expected negative influence on technical inefficiency. It might be surprising that age of the owners has positive impact on inefficiency. This result could be explained by the fact that, controlling for other factors, production decision, management capacity etc. of owners decline due to increase in the age of the owners. It is also appeared from Table 2 that the variables 'wages of labor', 'loan facility', and 'number of master weavers' become statistically insignificant. Therefore, these factors do not play any significant bearing in the case of influencing the efficiency of handloom weaving units.

Table 2. Regression Results of the Tobit Model.

\begin{tabular}{lllll}
\hline Variables & Marginal Effects & Std. Error & t-ratio & P-Value \\
\hline Constant & $0.246 * * *$ & 0.059 & 4.150 & 0.000 \\
Capital- labor ratio $\left(\mathrm{X}_{1}\right)$ & $-0.085^{* * *}$ & 0.011 & -7.491 & 0.000 \\
Education $\left(\mathrm{X}_{2}\right)$ & $-0.031 * * *$ & 0.011 & -2.828 & 0.006 \\
Experience $\left(\mathrm{X}_{3}\right)$ & $-0.091 * * *$ & 0.038 & -2.410 & 0.020 \\
Size of unit $\left(\mathrm{X}_{4}\right)$ & $-0.076^{* * *}$ & 0.026 & -2.879 & 0.006 \\
Age of owners $\left(\mathrm{X}_{5}\right)$ & $0.071 * *$ & 0.031 & 2.297 & 0.027 \\
Wages of labor $\left(\mathrm{X}_{6}\right)$ & 0.019 & 0.080 & 0.230 & 0.819 \\
Loan facility $\left(\mathrm{X}_{7}\right)$ & -0.003 & 0.004 & -0.634 & 0.529 \\
No. of master weaver & -0.008 & 0.006 & -1.306 & 0.198 \\
$\left(\mathrm{X}_{8}\right)$ & & & & 0.000 \\
Likelihood ratio test & $-19.284 * * *$ & & & \\
\hline
\end{tabular}

Source: Authors' own calculation; Note: $* * *$ and $* *$ indicate statistically significant at $1 \%$ and $5 \%$, respectively.

The coefficient of capital-labor ratio with the value of 0.085 has negative impact on inefficiency of handloom units and it is statistically significant at $1 \%$ level. This indicates that the marginal effect would reduce inefficiency by $8.5 \%$ if the owners increase the capital-labor ratio at $100 \%$. The coefficient of education with the value of -0.031 , statistically significant at $1 \%$ level, has also positive impact on efficiency of producing cloth by handloom units. It might be the case that comparatively educated owners easily make their industry more efficient through applying their knowledge on marketing process, production process, management system etc. Moreover, the educated owners have more access to information as well as to understand the market condition (price of yarn, labor, tools \& equipment etc.). The value of coefficient of experience is -0.091 and it has significant (statistically significant at $1 \%$ level) positive impact on the efficiency of handloom units. It means that an increase in experience of owners increases the efficiency of handloom units. Therefore, it could be concluded that comparatively experienced owners easily make their industry more efficient because the experienced owners can produce more qualified products by using their skill. The value of the coefficient of industry size is -0.076 , statistically significant at $1 \%$ level, 
implies that larger size reduced inefficiency of handloom units in Kumarkhali Upazila of Kushtia District. This result supports that an additional loom may increase the efficiency of the units. The owners who have large unit are more efficient than small units. It might be a fact that a large unit can use high quality wooden-made machines (looms) which increase their production. Moreover, the owners who have large unit get the facilities of scale effect. The large amount of production may increase the productivity and may decreases the average cost of production of the units. The coefficient of age of owners has significant (statistically significant at $5 \%$ level) negative impact on efficiency. It means that, controlling for other factors, the efficiency of handloom industry decrease due to the increase in the age of owners. It may be production decision, management capacity etc. of owners decline due to the increase of age. The likelihood ratio test, significant at $1 \%$ level, shows that all the explanatory variables used in the model are jointly significant.

\section{Conclusion}

It is found from the empirical data analyses that technical inefficiency exists in production among the handloom weaving units operating in Kumarkhali Upazila of Kushtia District in Bangladesh. Within the limitation of the data availability, we have also been able to identify and estimate the factors determining technical inefficiency existing in the handloom industry. The factors that have significant impacts on technical inefficiency are capital-labor ratio, education, experience of owners, size of unit, and age of owners. The result suggests that capital-labor ratio, education, experience, size of unit, and age of owners are vital factors to be considered seriously when policy-makers deliberate on the way to reduce inefficiency of handloom industry.

\section{References}

[1] Ahmed, M.U. (1999). Development of Small Scale Industries in Bangladesh in the New Millennium: Challenges and Opportunities. Asian Affairs, 21(1).

[2] Amemiya, T. (1973). Regression Analysis When the Dependent Variable is Truncated Normal. Econometrica, 4(6), 997-1016.

[3] Chowdhury, N. (1981). Relative Efficiency of Alternative Techniques in Cotton Weaving Industry of Bangladesh: A Case Study. The Bangladesh Development Studies, 9(3), 4566.
[4] Coelli, T., Rao, D. S. \& Battese G. E. (1998). An Introduction to Efficiency and Productivity Analysis. Kluver Academic Publishers, Norwell, MC. 1-319.

[5] Farrell, J. J. (1957). The Measurement of Productivity Efficiency. Journal of the Royal Statistical Society, Series A (120), 253-90.

[6] Featherstone, M., Allen M., Langemeier, R., and Ismet, M. (2004). A Non-parametric Analysis of Efficiency for a Sample of Kansas Beef Cow Farms. J. Agri. And Appl. Econ., 29(1), 175-84.

[7] GoB (Government of Bangladesh), Bangladesh Bureau of Statistics (BBS, 2003), Statistical Yearbook of Bangladesh.

[8] Islam, M. K. and Hossain M. E. (2014). Contribution of Factor Costs to Gross Return of Handloom Weaving Industry in Kumarkhali Upazila of Kushtia District of Bangladesh. Bangladesh Arthoniti Samity Samoyiki,_2014:41-50.

[9] Islam, M. K. and Hossain M. E. and Ghosh, B. C. (2013). Cost-Benefit Analysis of Handloom Weaving Industry in Kumarkhali Upazila of Kushtia District, Bangladesh. Development Compilation, 09(01), 64-72.

[10] Jaforulla, M. (1999). Production Technology, Elasticity of Substitution and Technical Efficiency of the Handloom Textile Industry of Bangladesh. Applied Economics, 31(4), 437-442.

[11] McKay, L. (1984). An Analysis of Assistance to Textile Weaving in Bangladesh. TIP Reform Programme, Government of Bangladesh.

[12] Rahman, A. (1980). A Study on the Relative Efficiency of Handlooms and Small Power Looms vs. Large Mills. Bangladesh Institute of Development Studies (BIDS), Dhaka, Bangladesh.

[13] Rahman M. M. (2013). Prospects of Handloom Industries in Pabna District, Bangladesh. Global Journal of Management and Business Research Interdisciplinary, 13(5), 8-18.

[14] Raihan, M. A. (2010). Handloom: An Option to Fight Rural Poverty in Bangladesh. Asia-Pacific Journal of Rural Development, 20(1), 113-130.

[15] Tanusree, S. (2015). A Study of the Present Situation of the Traditional Handloom Weavers of Varanasi, Uttar Pradesh. India International Research Journal of Social Sciences, 4(3), 48-53.

[16] Wasow, B., Farouque, A. and Gani M. O. (1984). The Effects of Policy on the Choice of Technique in Textile Weaving. TIP Reform Programme, Government of Bangladesh. 